\title{
PENGARUH METODE EKSPERIMEN TERHADAP PENGUASAAN GRAFIK KINEMATIKA KONSEP GLB DAN GLBB PADA MAHASISWA FISIKA UNIVERSITAS MUHAMMADIYAH MATARAM
}

\author{
Khairil Anwar $^{(1)}$, M. Firman Ramadhan ${ }^{(2)}$ \\ Program Studi Pendidikan Fisika, Universitas Muhammadiyah Mataram \\ Kampus Induk, Jl.KH. Ahmad Dahlan N0.1 Pagesangan Mataram, Telp (0370) 630775 \\ e-mail : hairil_physic@yahoo.com
}

\begin{abstract}
ABSTRAK
Hasil observasi menggambarkan tentang kesulitan yang dialami mahasiswa ketika memahami grafik kinematika, termasuk kesalahan dalam menafsirkan grafik sebagai gambar, juga mengalami kesulitan ketika memisahkan arti posisi, kecepatan, dan percepatan yang diperbandingkan dengan grafik waktu. Ini disebabkan karena metode pengajaran dalam perkuliahan biasanya mengacu pada metode ceramah saja, oleh karena itu dosen harus termotivasi untuk menerapkan metode mengajar yang tepat sesuai dengan materi ajar. Untuk mengetahui sejauh mana peningkatan pemahaman mahasiswa, maka telah dilakukan penelitian tentang "Pengaruh Metode Eksperimen Terhadap Penguasaan Grafik Kinematika Konsep GLB dan GLBB pada Mahasiswa Fisika Universitas Muhammadiyah Mataram Tahun Akademik 2011/2012”, dengan tujuan untuk mengetahui perbedaan antara hasil belajar fisika mahasiswa dan mengetahui metode mana yang lebih baik untuk diterapkan dalam perkuliahan tentang konsep grafik gerak lurus. Identifikasikan kemampuan mahasiswa didasarkan pada kelompok eksperimen dan kelompok kontrol (ceramah) yang dijadikan sebagai subyek penelitian (sampel) yang terbentuk dari dua kelas semester III, dengan populasi seluruh mahasiswa fisika. Teknik pengumpulan data adalah dokumentasi dan tes, dimana instrumen teruji terlebih dahulu kelayakannya. Analisis data digunakan Uji Normalitas, dan Uji Homogenitas. Selanjutnya diolah dengan menggunakan uji-t untuk membuktikan hipotesis. Berdasarkan hasil analisis kemampuan akhir mahasiswa yang mendapat skor total kategori tinggi pada kelas eksperimen lebih banyak (ada 15 orang) dibandingkan dengan mahasiswa kelas kontrol (hanya ada 7 orang). Uji hipotesis menggunakan uji-t dua pihak, diperoleh $t_{\text {hitung }}(3,274)$ lebih besar dari $t_{\text {tabel }}(1,993)$ pada taraf signifikan $5 \%$ dan derajat bebas 82 , ini berarti bahwa hipotesis $\mathrm{H}_{1}$ diterima yang berarti ada perbedaan yang signifikan antara hasil belajar fisika pada mahasiswa yang mendapat pembelajaran grafik kinematika konsep GLB dan GLBB dengan metode eksperimen dengan nilai rata-rata klasikal $=7,79$. Sedangkan hasil belajar fisika pada mahasiswa kelas kontrol adalah $=6,38$. Hal ini membuktikan pembelajaran grafik kinematika konsep GLB dan GLBB dengan metode eksperimen ternyata efektif dalam meningkatkan hasil belajar fisika mahasiswa terhadap materi grafik kinematika konsep GLB dan GLBB.
\end{abstract}

\section{PENDAHULUAN}

Hasil riset menunjukkan bahwa pembelajaran fisika masih memprihatinkan. Rendahnya prestasi belajar fisika yang ditunjukkan dalam nilai rata-rata akhir semester mahasiswa masih sangat jauh dari yang diharapkan, salah satu penyebabnya karena masih banyak dijumpai metode pengajaran yang mengacu pada metode ceramah saja, sehingga harus diupayakan suatu pendekatan dan metode pembelajaran yang tepat yang harus diterapkan oleh dosen agar dapat meningkatkan hasil dan prestasi belajar mahasiswa.

Dari berbagai penelitian dan pengembangan program melalui pendekatan yang baik dapat memberikan hasil yang lebih baik, karena salah satu faktor yang dapat mempengaruhi hasil belajar diantaranya adalah pendekatan pembelajaran yang tepat. Upaya ini menjadi sangat penting sebab hanya dengan melalui pendekatan pembelajaran yang tepat mahasiswa dapat meningkatkan pemahamannya terhadap konsep-konsep fisika yang sedang dipelajari.

Permasalahan di atas perlu diupayakan pemecahannya, salah satunya melakukan tindakan yang dapat mengubah suasana perkuliahan yang melibatkan mahasiswa untuk lebih aktif dalam perkuliahan, yaitu melalui pembelajaran dengan 
menghadapkan mahasiswa pada obyek yang nyata (melakukan percobaan) serta melibatkan pengetahuan awal mahasiswa. Melakukan percobaan dalam pembelajaran adalah salah satu upaya menanamkan konsep kepada mahasiswa, karena dengan percobaan terdapat keuntungankeuntungan sebagai berikut : ${ }^{(1)}$ Mahasiswa lebih percaya pada kebenaran konsep yang telah dicoba sendiri, $\quad{ }^{(2)}$ hasil belajar yang diperoleh mahasiswa bersifat retensi (tahan lama) dan internalisasi (menyatu dalam jiwa mahasiswa), dan ${ }^{(3)}$ memperkaya pengalaman dengan hal yang bersifat objektif. Dengan demikian, pembelajaran secara langsung pada obyek yang sedang dipelajari memungkinkan meningkatkan perolehan pengetahuan sesuai dengan harapan (Kurniawan, 2000). Sebagaimana Edgar Dale mengutarakan bahwa pengalaman yang paling bermakna adalah pengalaman langsung dan bertujuan, suatu pengalaman langsung melihat benda atau peristiwa asli namun telah direncanakan terlebih dahulu, sehingga para mahasiswa akan mendapatkan hasil keilmuan, nilai dan sikap yang optimal (Supriyadi, 2002). Eksperimen atau kegiatan praktikum adalah salah satu cara yang tepat untuk memudahkan memahami suatu teori, sehingga mahasiswa mampu mencari dan menemukan sendiri berbagai jawaban atas persoalan-persoalan yang dihadapinya, sehingga kelak akan terbiasa untuk berfikir ilmiah (Roestiyah, 2008). Sesuai dengan kurikulum perguruan tinggi, matakuliah mekanika pada pokok bahasan kinematika perlu ditunjang dengan praktikum atau eksperimen, oleh karena itu eksperimen untuk menggambarkan proses dan konsep tentang gerak secara grafis sangat diperlukan untuk mengatasi kesulitan pemahaman teori-teori tentang kinematika.

Pokok bahasan tentang kinematika merupakan materi permulaan dalam perkuliahan fisika dasar dan mekanika. Kinematika adalah bidang ilmu fisika yang menjelaskan gerak benda, yang deskripsinya dapat melalui representasi verbal, diagram, grafik, dan persamaan matematika. Pengajaran kinematika ditujukan untuk mengembangkan penguasaan konsep tentang gerak benda agar seseorang dapat memahami atau menjelaskan gejala gerak dari

\section{KAJIAN TEORI}

\section{Konsep Tentang Belajar Mengajar}

Beberapa pendapat tentang belajar diantaranya :

1. Menurut Dimyati dan Mudjiono (1996 : 7) belajar merupakan tindakan dan perilaku peserta didik yang kompleks.

2. Menurut Morgan belajar adalah setiap perubahan yang relatif menetap dalam tingkah benda-benda nyata yang terlihat di alam. Konsepkonsep dasar kinematika, meliputi konsep perpindahan, kecepatan, dan percepatan dalam kaitannya dengan waktu. Bentuk gerakan benda dapat diketahui dengan menelaah persamaan, diagram, dan grafik dari konsep dasar tersebut sebagai fungsi waktu (Ishafit, 2005).

Dengan menyadari pentingnya pemahaman terhadap grafik kinematika, maka dalam proses evaluasi perkuliahan kinematika muncul kebutuhan akan pengukuran terhadap pemahaman tersebut. Terkait dengan grafik, Robert J. Berchner dan Kimberly D. C Benjamin yang dikutip Hariyanto (2004) menyatakan bahwa masih ditemui beberapa kesulitan yang dialami mahasiswa ketika menemui grafik kinematika, termasuk juga kesalahan dalam menafsirkan grafik sebagai gambar. Mereka juga mengalami kesulitan ketika memisahkan arti posisi, kecepatan, dan percepatan yang diperbandingkan dengan grafik waktu. Oleh karena itu, untuk mengetahui sejauh mana peningkatan pemahaman konsep GLB dan GLBB melalui konsep grafik kinematika mahasiswa fisika Universitas Muhammadiyah Mataram dengan metode eksperimen, maka akan diidentifikasikan kemampuan siswa berdasarkan kelompok eksperimen dan kelompok kontrol (ceramah) yang dijadikan sebagai subyek penelitian. Untuk itu berdasarkan uraian di atas, penulis melakukan penelitian tentang "Pengaruh Metode Eksperimen Terhadap Penguasaan Grafik Kinematika Konsep GLB dan GLBB pada Mahasiswa Fisika Universitas Muhammadiyah Mataram Tahun Akademik 2011/2012”, dengan tujuan untuk mengetahui perbedaan antara penguasaan materi oleh mahasiswa fisika tentang grafik kinematika konsep GLB dan GLBB menggunakan metode eksperimen dengan metode ceramah serta mengetahui metode mana yang lebih baik untuk diterapkan dalam meningkatkan penguasaan materi perkuliahan tentang grafik kinematika konsep GLB dan GLBB pada mahasiswa pendidikan fisika Universitas Muhammadiyah Mataram. Sehingga diharapkan dapat memberikan manfaat pada bidang pendidikan fisika.

laku yang terjadi sebagai suatu hasil dari latihan atau pengalaman (Sagala, $2003: 13$ ).

3. Menurut Ngalim Purwanto mengemukakan belajar adalah setiap perubahan yang relatif menetap dalam tingkah laku, yang terjadi sebagai suatu hasil dari latihan atau pengalaman (Adrian, 2004). 
4. Menurut Spears : Learning to observe, to read, to imited, to try something themselves, to listen, to follow direction, dimana pengalaman itu dapat diperoleh melalui panca indera (Adrian, 2004).

5. Menurut Cronbach berpendapat 'learning is shown by a change in behavior as result of experience : belajar dapat dilakukan secara baik dengan jalan mengalami (Adrian, 2004).

Dari pendapat-pendapat tersebut di atas dapat disimpulkan bahwa belajar adalah segenap rangkaian kegiatan atau aktivitas yang dilakukan secara sadar oleh seseorang dan mengakibatkan perubahan dalam dirinya berupa penambahan pengetahuan atau kemahiran berdasarkan alat indera dan pengalamannya.

\section{Mengajar}

Untuk memperoleh pengertian mengajar secara tepat, akan diuraikan beberapa pendapat tentang mengajar diantaranya adalah :

1) Menurut Nasution berpendapat bahwa mengajar adalah suatu aktivitas mengorganisasi atau mengatur lingkungan dengan sebaik-baiknya dan menghubungkannya dengan anak sehingga terjadi proses belajar (Adrian, 2004).

2) Menurut Biggs yang dikutip Adrian (2004), seorang pakar psikologi membagi konsep mengajar menjadi tiga macam pengertian yaitu :

a. Pengertian kuantitatif dimana mengajar diartikan sebagai transmission of knowledge, yakni penularan pengetahuan. Dalam hal ini dosen hanya perlu menguasai pengetahuan bidang studinya dan menyampaikan kepada mahapeserta didik dengan sebaik-baiknya. Masalah berhasil atau tidaknya bukan tanggung jawab pengajar.

b. Pengertian institusional yaitu mengajar berarti "the efficient orchestration of teaching skills”, yakni penataan segala kemampuan mengajar secara efisien. Dalam hal ini pengajar dituntut untuk selalu siap mengadaptasikan berbagai teknik mengajar terhadap mahapeserta didik yang memilki berbagai macam tipe belajar serta berbeda bakat, kemampuan, dan kebutuhannya.

c. Pengertian kualitatif dimana mengajar diartikan sebagai the facilitationof learning, yaitu upaya membantu memudahkan kegiatan belajar mahapeserta didik mencari makna dan pemahamannya sendiri.

3) Menurut Hamalik (2001 : 44-52) a. Mengajar adalah menyampaikan pengetahuan kepada mahapeserta didik di lingkungan belajar formal.

b. Mengajar adalah mewariskan kebudayaan kepada generasi muda melalui lembaga pendidikan.

c. Mengajar adalah usaha mengorganisasi lingkungan sehingga menciptakan kondisi belajar.

d. Mengajar adalah memberikan bimbingan belajar kepada yang membutuhkan.

e. Mengajar adalah kegiatan mempersiapkan generasi untuk menjadi warga negara yang baik sesuai dengan tuntutan masyarakat.

4). Menurut Syaiful Bahri Djamarah dan Aswan Zain (1995 : 45) mengajar adalah suatu proses, yaitu proses mengatur, mengorganisasi lingkungan yang ada, sehingga dapat mnumbuhkan dan mendorong masyarakat melakukan proses belajar.

Berdasarkan definisi - definisi mengajar dari pakar di atas dapat ditarik kesimpulan bahwa mengajar adalah suatu aktivitas yang tersistem dari sebuah lingkungan yang terdiri dari pendidik, pengajar, pembimbing dan peserta didik untuk saling berinteraksi dalam melakukan suatu kegiatan sehingga proses belajar dan tujuan pengajaran tercapai.

\section{Metode Mengajar (Pembelajaran)}

Metode mengajar adalah cara yang digunakan pengajar dalam menyampaikan materi pembelajaran dan mendinamisasikan proses belajar- mengajar (Soetopo, 2005 : 152). Metode adalah suatu cara yang dipergunakan untuk mencapai tujuan yang ditetapkan. Dalam kegiatan belajar-mengajar, metode diperlukan oleh pengajar dan penggunaannya bervariasi sesuai dengan tujuan yang ingin dicapai setelah pengajaran berakhir (Djamarah, dan Zain, 1995: 53). Metode mengajar adalah cara yang digunakan dalam mengorganisasikan kelas pada umumnya atau dalam menyajikan bahan perkuliahan pada khususnya (Sagala, 2003 : 169). Sedangkan metode pembelajaran adalah cara melakukan atau menyajikan, menguraikan, memberi contoh, memberi latihan isi pelajaran kepada masyarakat untuk mencapai tujuan tertentu (Yamin, 2006 : 135).

Jadi pada dasarnya metode mengajar adalah suatu cara yang digunakan oleh pengajar untuk menyampaikan bahan ajar kepada mahapeserta didik, supaya menjadi paham dan mengerti apa yang telah diajarkan. 


\section{Metode Ceramah (Preaching Method)}

Metode ceramah atau kuliah (lecture) merupakan cara belajar-mengajar dimana disajikan oleh pengajar secara monologue (sologuy) sehingga pembicaraan lebih bersifat satu arah (one way communication). Metode caramah sangat populer, karena sejak zaman dahulu metode ini telah digunakan sebagai alat komunikasi lisan antara pengajar dan peserta didik dalam proses belajarmengajar, bahkan kemungkinan metode ceramah merupakan metode pengajaran yang paling awal digunakan dalam proses pembelajaran dibandingkan dengan metode-metode yang lain (Surakhmad, 1990 : 98).

\section{Metode Ekperimen(Eksperimental Method)}

Metode Eksperimen adalah cara penyajian pelajaran, dimana peserta didik melakukan percobaan dengan mengalami dan membuktikan sendiri sesuatu yang dipelajari (Djamarah dan Zain, 1995 : 95). Eksperimen adalah percobaan untuk membuktikan suatu pertanyaan atau hipotesis tertentu. Eksperimen bisa dilakukan pada suatu laboratorium atau di luar laboratorium, pekerjaan eksperimen mengandung makna belajar untuk berbuat, karena itu dapat dimasukkan ke dalam pembelajaran. Metode eksperimen adalah cara penyajian bahan pelajaran dimana peserta didik melakukan percobaan dengan mengalami untuk

\section{METODOLOGI}

Jenis penelitian ini adalah penelitian eksperimen dengan pendekatan yang digunakan adalah pendekatan kuantitatif. Identifikasikan kemampuan mahasiswa didasarkan pada kelompok eksperimen dan kelompok kontrol (ceramah) yang dijadikan sebagai subyek penelitian (sampel) dengan populasi seluruh mahasiswa fisika. Desain dalam penelitian ini dapat digambarkan secara skematis membuktikan sendiri sesuatu pertanyaan atau hipotesis yang dipelajari (Sagala, $2003: 220$ ).

\section{Grafik kinematika}

Untuk menggambarkan pergeseran, kecepatan, dan percepatan suatu gerak benda diperlukan grafik kinematika. Grafik untuk menggambarkan pergeseran menggunakan grafik posisi terhadap waktu.
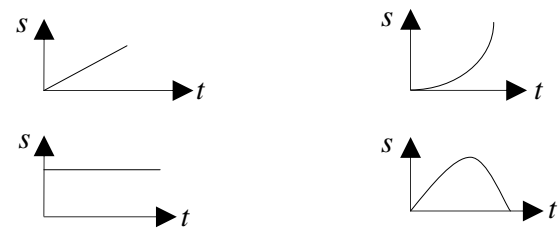

Gambar 1. Grafik posisi (s) terhadap waktu $(t)$

Kecepatan sesaat ditampilkan secara grafik sebagai kemiringan kurva $x$ terhadap $t$ dalam satu dimensi baik kecepatan sesaat dapat bernilai positif atau negative.

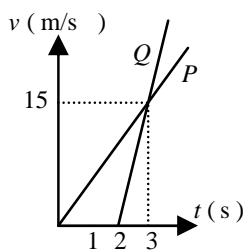

Gambar 2. Grafik kecepatan (v) terhadap waktu

yang disajikan pada Tabel 3.1. Teknik pengumpulan data adalah dokumentasi dan test, dimana instrumen diuji terlebih dahulu dalam aspek Validitas, Reliabel, Tingkat Kesukaran, dan Daya Beda. Analisis data digunakan Uji Normalitas, dan Uji Homogenitas, selanjutnya diolah dengan menggunakan uji-t untuk membuktikan hipotesis yang ada.

Tabel 1. Desain Penelitian.

\begin{tabular}{|l|c|c|c|}
\hline \multicolumn{1}{|c|}{ Kelompok / Kelas } & Pretest & Perlakuan & Postest \\
\hline Kelas Eksperimen (III-A) & $\mathrm{O}$ & $\mathrm{P}_{1}$ & $\mathrm{O}_{\text {eks }}$ \\
\hline Kelas Kontrol (III-B) & $\mathrm{O}$ & $\mathrm{P}_{2}$ & $\mathrm{O}^{\prime}{ }_{\text {kntl }}$ \\
\hline
\end{tabular}

\section{HASIL DAN PEMBAHASAN}

Diskripsi kemampuan awal mahasiswa fisika diketahui bahwa pada mahasiswa yang akan menjadi kelas eksperimen, diperoleh nilai tertinggi $=7,5$, terendah $=4,3$, rata-rata $(\bar{X})=5,77$. Sedangkan pada mahasiswa yang akan menjadi kelas kontrol diperoleh nilai tertinggi $=7,7$, terendah $=4,3$, rata-
$\operatorname{rata}(\bar{X})=5,89$, dimana masing-masing sampel merupakan data yang berdistribusi normal dan homogen. Sedangkan deskripsi skor total hasil belajar mahasiswa dapat dilihat pada Tabel 2. 
Tabel 2. Deskripsi Hasil Belajar

\begin{tabular}{|l|c|c|c|c|c|}
\hline \multirow{2}{*}{ Sampel } & \multicolumn{4}{l|}{ Parameter } & \multicolumn{4}{l|}{} \\
\cline { 2 - 6 } & tertinggi & terendah & $\bar{X}$ & $\mathrm{SD}$ & $\mathrm{S}^{2}$ \\
\hline Kelompok eksperimen $\left(\mathrm{X}_{1}\right)$ & 11 & 4 & 7,79 & 1,91 & 3,64 \\
\hline Kelompok kontrol $\left(\mathrm{X}_{2}\right)$ & 11 & 3 & 6,38 & 2,02 & 4,10 \\
\hline
\end{tabular}

Dimana skor total hasil belajar pada masingmasing sampel merupakan data yang berdistribusi normal dan homogen pada taraf signifikan $5 \%$, sebagaimana ditunjukkan dalam Tabel 3 dan Tabel 4.

Tabel 3. Uji Normalitas Skor Total Prestasi Belajar

\begin{tabular}{|l|c|c|c|c|}
\hline \multicolumn{1}{|c|}{ Sampel } & $\chi^{2}{ }_{\text {hit }}$ & $\chi^{2}{ }_{\text {tabel }}$ & $\mathrm{dk}$ & Ket. \\
\hline Kls eksperimen & 3,498 & 11,070 & 5 & normal \\
\hline Kls Kontrol & 7,642 & 11,070 & 5 & normal \\
\hline
\end{tabular}

Tabel 4. Hasil Uji Homogenitas

\begin{tabular}{|c|c|c|c|}
\hline$\chi^{2}{ }_{\text {hitung }}$ & $\chi^{2}{ }_{\text {tabel }}$ & $\mathrm{dk}$ & Keterangan \\
\hline 0,145 & 3,841 & 1 & homogen \\
\hline
\end{tabular}

Pada Tabel 5 disajikan ringkasan hasil uji $t$ dua pihak pada skor total hasil belajar fisika.

\begin{tabular}{|c|c|c|c|}
\hline$t_{\text {hitung }}$ & $t_{\text {tabel }}$ & Taraf signifikan & $\mathrm{dk}$ \\
\hline 3,274 & 1,993 & $5 \%$ & 82 \\
\hline Dari & Tabel & 5. diketahui $t_{\text {hitung }}(3,274)>$ \\
$t_{\text {tabel }}(1,993)$ pada taraf signifikan $5 \%$ dan derajat
\end{tabular}

\section{KESIMPULAN DAN SARAN}

Berdasarkan deskripsi data dari hasil dan pembahasan dalam penelitian ini dapat disimpulkan bahwa; ${ }^{1)}$ Ada perbedaan yang signifikan antara hasil belajar fisika pada mahasiswa yang mendapat pembelajaran grafik kinematika konsep GLB dan GLBB dengan metode eksperimen terhadap metode konvensional. ${ }^{2}$ Pembelajaran grafik kinematika konsep GLB dan GLBB dengan metode eksperimen lebih efektif dalam meningkatkan hasil belajar mahasiswa, dibandingkan dengan pembelajaran tanpa metode eksperimen. Berdasarkan kesimpulan di atas, peneliti menyarankan bahwa metode

\section{DAFTAR PUSTAKA}

Adrian. 2004. Metode Mengajar Berdasarkan Tipologi Belajar Siswa. Diambil pada tanggal 6 agustus 2011 dari http://artikel.us/art 0565.html.

Arikunto, S. 2002. Prosedur Penelitian (Suatu Pendekatan Praktek). PT. Bumi Aksara : Jakarta. bebas 82, hal ini berarti bahwa hipotesis $H_{0}$ ditolak dan hipotesis $H_{1}$ diterima.

Hasil uji homogenitas nilai kemampuan awal menunjukkan bahwa mahasiswa yang akan mendapat pembelajaran grafik kinematika konsep GLB dan GLBB dengan metode eksperimen dan tanpa eksperimen (metode konvensional), keduanya berasal dari populasi yang memiliki nilai kemampuan awal yang setara (homogen). Sedangkan brdasarkan Tabel 5 membuktikan bahwa pembelajaran grafik kinematika konsep GLB dan GLBB dengan metode eksperimen ternyata lebih efektif secara signifikan dalam meningkatkan hasil belajar mahasiswa dari pada metode konvensional. Ini berarti bahwa hipotesis $\mathrm{H}_{0}$ ditolak dan $\mathrm{H}_{1}$ diterima. Sehingga disimpulkan bahwa ada perbedaan yang signifikan antara rata-rata skor total prestasi belajar fisika pada mahasiswa yang mendapat pembelajaran grafik kinematika konsep GLB dan GLBB dengan metode eksperimen

eksperimen hendaknya lebih dioptimalkan dalam pembelajaran fisika, dan bagi peneliti lain khususnya yang berkompeten dalam bidang studi fisika, hasil penelitian ini dapat dijadikan sebagai bahan pertimbangan untuk melakukan penelitian dalam ruang lingkup yang lebih luas, topik yang berbeda dan metode yang berbeda pula. 
Gulo, W. 2002. Strategi Belajar Mengajar. PT. Gramedia : Jakarta.

Hariyanto. 2004. "Kemampuan Mahasiswa dalam Menampilkan Gejala Gerak ke dalam Grafik”. Skripsi tidak diterbitkan. Program Studi Pendidikan Matematika. Universitas Ahmad Dahlan : Yogyakarta.

Hamalik, Oemar. 2001. Proses Belajar Mengajar. Bumi Aksara : Jakarta.

Ishafit. 2005. Metode Riset Pendidikan Fisika. Jurdik Fisika JPMIPA : UAD.

Kurniawan, D. 2000. “Upaya Mengaktifkan Siswa dalam Pembelajaran Getaran dan Gelombang Melalui Pendekatan Konstruktivisme pada Siswa SMU Swadhipa Natar Tahun Ajaran 1999/2000”. Diambil pada tanggal 1 April 2011 dari

http://www.homepagez.com/jombang/skripsi.ht $\underline{\mathrm{ml}}$.

Poerwodarminto. 1984. Kamus Umum Bahasa Indonesia. Balai Pustaka : Jakarta.

Roestiyah. 2008. Strategi Belajar Mengajar. Jakarta : Rineka Cipta.

Syaifuddin, Azwar. 2007. Penyusunan Skala Psikologi. Yogyakarta: Pustaka Pelajar.

Soetopo, Hendyat. 2005. Pendidikan dan Pembelajaran. UMM : Malang.
Sudjana. 1989. Metoda Statistika. Tarsito : Bandung.

Supriyadi. 2000. Panduan untuk Merancang Eksperimen Fisika Sederhana. Jurdik Fisika FMIPA : UNY.

2003. Fisika dan Konsep Sains Terpakai dalam Konteks Kompetensi Model Pembelajaran dan Portofolio. Tempelsari Books Company. 2006. Makalah untuk Lokakarya Konsep Media untuk Pembelajaran Fisika. Jurdik Fisika FMIPA : UNY.

Syaiful Bahri,. Djamarah,. dan Aswan Zain. 1995. Strategi Belajar Mengajar. Rineka Cipta : Jakarta.

Sagala, Syaiful. 2003. Konsep dan Makna Pembelajaran. Alfabeta : Bandung.

Surakhmad, Winarno.1990. Pengantar Interaksi Mengajar-Belajar, Dasar dan Teknik Metodologi Pengajran. Tarsito : Bandung.

Sears dan Zemansky. 2002. Fisika Universitas Jilid I. Erlangga : Jakarta.

Yamin, Martinis. 2003. Strategi Pembelajaran Berbasis Kompetensi. Gaung Persada Press : Jakarta.

2006. Profesionalisasi Guru dan Implementasi Kurikulum Berbasis Kompetensi. Gaung Persada Press : Jakarta. 